\title{
Challenges Towards Reducing Illegal Dumping Activities in the Construction Industry
}

\author{
Mohd Hilmi Izwan Abd Rahim ${ }^{*}$, Sulzakimin Mohamed ${ }^{2}$, Narimah Kasim³, \\ Mazianah Rahmat ${ }^{4}$, Nurdiana $\mathrm{Azmi}^{5}$
}

${ }^{1,2,3}$ Department of Construction Management, Faculty of Technology Management and Business, Universiti Tun Hussein Onn Malaysia, Batu Pahat, 86400 Parit Raja, Johor, MALAYSIA

4,5 Department of Quantity Surveying, Lee Kong Chian Faculty of Engineering and Science, Universiti Tunku Abdul Rahman, Sungai Long Campus, Bandar Sg Long, 43000 Kajang, Selangor, MALAYSIA

*Corresponding Author

DOI: https://doi.org/10.30880/jstard.2021.03.02.009

Received 15 November 2021; Accepted 20 October 2021; Available online 15 December 2021

\begin{abstract}
This nowadays an increasing number of construction projects in Malaysia have contributed to the production of construction waste which has had a negative impact on the environment, especially through illegal dumping. The increasing number of illegal dumping activities is a sign that construction waste management needs to be examined. To date, a comprehensive criterion for construction waste management, in developing countries is still not clearly defined. Therefore, the objectives of this paper are to investigate current illegal dumping activities, and identify the challenges towards reducing illegal dumping activities in the Malaysian construction industry. Hence, this research conducted interviews with 20 expert stakeholders related to construction waste management in order to scrutinise illegal dumping activities in Malaysia. The data from these semi-structured interviews were analysed by content analysis. The findings are used to determine the current challenges for reducing illegal dumping activities in the Malaysian construction industry. The elements in the current findings are potentially to improve construction waste management in order to archive the proper construction waste management. Finally, this findings will help to identify strategies to reduce illegal dumping activities and to enhance challenges towards reducing illegal dumping activities in the Malaysian construction industry.
\end{abstract}

Keywords: Illegal dumping activities, construction waste, challenges, Malaysia construction industry

\section{Introduction}

An important problem that adversely affects the environmental is the generation of construction waste. The inappropriate management of waste generated in construction sites can lead to the increase in waste being dumped at landfills and illegal dumping. Compared to other countries, especially in developing countries the government has applied appropriate planning for waste management either domestic waste or construction waste [1], [2], [3], [4]. In the United Kingdom (UK), 220 million tonnes of construction and demolition waste were produced. It shows the high number of construction waste has been generated in develop country. To date, UK has develop the solution by implementing the combination of waste management regulations, economic instruments and voluntary agreements by the government to reduce waste generation. It shows that, develop country has seriously moving forward on construction waste management solution. On the other hand, it shows that the UK government is proactively involved in construction waste management $[5],[4])$.

Previous research have highlighted that the challenges of proper construction waste management practices in Malaysia have led to the increasing number of illegal dumping activities [6], [1], [7], [4]. This challenges id due to increasing number of construction activities and lack of awareness among all the construction players to the proper 
construction waste management. Improper construction waste management has definitely contributed to the increase in illegal dumping activities. In the construction industry, $6 \%$ to $8 \%$ of the waste for residential buildings is made up of tiles, $4 \%$ to $20 \%$ of waste for commercial buildings is made up of mix concrete whereas $15 \%$ consists of timber or wood [8]. According to the previous studies, the highest percentages of waste materials found in illegal dumping areas consist of wood, mix concrete, tiles and bricks [1], [9]. On the other hand, the increasing production of construction waste at construction sites has obviously contributed to illegal dumping activities. Consequently, efficient construction waste management for construction projects is needed [10], [11], [8], [12]. Hence this paper focuses on challenges towards reducing illegal dumping activities in the Malaysian construction industry. Thus, this paper aims to identify the strategy to overcome the challenges of construction waste management towards reducing illegal dumping activities.

\section{Construction Waste Management in Construction Industry}

The excesses of construction waste produced from the range of human activities add to environment problems [13], [14], [15]. Construction waste as those non-useable construction materials resulting from the activities of site clearance and from construction projects such as concrete, timber and others material contributed to waste production. Additionally, [15] defined construction waste as valuable, undesirable or scrap materials resulting from human activities and are not free-flowing. Nevertheless, nowadays it is more necessary to decrease the waste generated from human activities [16[, [8], [15].

\subsection{Construction Waste Management in Malaysia Construction Industry}

In Malaysia, the public sector is accountable for solid waste management. Nevertheless, the government has procured the services of private contractors in waste management. Construction waste operations namely are funded by several means in Malaysia. For instance, fees charged for services and subsidies from waste revenues received from government sources are some of the sources of funding for this sector [17]. Increasing construction activities in developing countries lead to excessive production of construction waste. Traditionally, construction waste has been managed by merely disposing them off at a disposal site or burning and burying them at the construction site [18]. Additionally, the current methods for managing construction waste include direct dumping in landfills [19]. In Malaysia, it is common practice for construction waste to be disposed at the same site as municipal solid waste. This method has become popular because it does not require adequate planning or advanced technology [20].

However, construction waste disposal has an enormous impact on the size of the disposal site, construction waste management cost and the environment [21]. While most construction wastes wind up in landfills, significant quantities are still being dumped at illegal dumpsites. Illegal dumping is a major challenge in many areas, and this raises concerns about safety, property value and the quality of life within the community [8]. In Malaysia, the dumping of waste at illegal dumping sites is a common practice. This is especially likely for industrial and construction wastes [9], [22], [12]. However, statistics on the volume of construction waste being dumped unlawfully are [23], [24]. The offence notices issued by SWCorp Malaysia have proved that the disposal of solid waste materials is increasing. The work done by the SWCorp Malaysia will help in reducing unlawful dumping of construction waste and improve compliance with construction parties.

\subsection{Issues in Construction Waste Management}

Construction waste is a prominent global issue and has adverse effects on the overall performance of a project, the society and the environment. Waste can be generated in various forms. In accordance with the increasing acceptance of sustainable development, efficient construction waste management should be emphasised. Construction waste management is an important function for improving waste management in construction projects. This is because inappropriate waste management can often affect the environment, the economy and society.

\subsubsection{Illegal Dumping Activities}

The construction industry has long been regarded as one of the main contributors of improper impacts social, economy and environment effect from the generation of waste. The demand for construction projects, especially in developing countries such as Malaysia, has generated to construction waste and the possibility of illegal dumping activities from the construction activities [1], 2012; [7], [2]. Additionally, waste can also be defined as unwanted or discarded materials produced by households, commercial institutions and industrial activities [8]. But in this research, construction waste is refer to the unwanted of construction material produced by the construction activities in site.

Furthermore, the rapid growth in population and change in lifestyle have increased illegal dumping activities throughout the world. The illegal dumping of construction waste leads to environmental issues. Additionally, illegal dumping activities involving construction waste generally refer to construction waste, demolition waste, renovation waste, earthworks and land clearing in public areas or unwanted places [2], [25]. The action of dumping waste in landfills 
is controlled by Act 672. It is compulsory for construction waste disposed at provided landfills. As reported by SWCorp Malaysia, illegal dumping activities are carried out in the construction industry in Malaysia.

\subsection{Challenges of Illegal Dumping Activities in Construction Waste Management}

In order to find the solution to a given problem, it is usually important to first identify the fundamental cause of the problem. Similarly, in order to successfully execute sustainable waste management, the problems that hamper its achievement must be identified, and actions must be taken to minimise illegal dumping activities in the Malaysian construction industry. As a result of identifying the issues encountered in the waste management industry in terms of reducing illegal dumping activities, both the private and governmental sectors can focus on resolving the issues to achieve proper waste management. It is imperative to overcome the challenges in order to increase the implementation of more efficient construction waste management. Table 1 shows the challenges faced in minimising illegal dumping activities based on a review of the extant literature.

Table 1 - Challenges in illegal dumping activities

\begin{tabular}{|c|c|}
\hline Challenges & Description \\
\hline $\begin{array}{l}\text { Inadequate technologies and } \\
\text { facilities [26] }\end{array}$ & $\begin{array}{l}\text { Present mediums such as landfilling are not sufficient to deal with the } \\
\text { ever-increasing rate of illegal dumping activities }\end{array}$ \\
\hline $\begin{array}{l}\text { The absence of a good recycling } \\
\text { market [11] }\end{array}$ & $\begin{array}{l}\text { Recycling requires aggressive marketing efforts to identify new markets } \\
\text { and sales at higher prices. }\end{array}$ \\
\hline Insufficient funds [26], [11] & $\begin{array}{l}\text { As waste minimisation needs high operational cost, numerous industry } \\
\text { practitioners are unwilling to adopt different techniques for reducing } \\
\text { illegal dumping activities. An incentive or appropriate fund may be a } \\
\text { motivation for applying proper waste management methods. }\end{array}$ \\
\hline $\begin{array}{l}\text { Insufficient regulations (Manaf et } \\
\text { al., 2011, [11] }\end{array}$ & $\begin{array}{l}\text { Regulations are required to prevent industry practitioners from engaging } \\
\text { in illegal dumping activities. Still, it is challenging to create an excellent } \\
\text { management system for construction waste which is integrated, cost- } \\
\text { effective, sustainable, and acceptable to the community, with an emphasis } \\
\text { on environmental conservation and technology selection. }\end{array}$ \\
\hline $\begin{array}{l}\text { Lack of awareness (Manaf et al., } \\
\text { 2011, [11] }\end{array}$ & $\begin{array}{l}\text { Although several policies have been developed, most industry } \\
\text { practitioners do not still realise the significance of utilising efficient waste } \\
\text { management systems especially for reducing illegal dumping activities } \\
\text { based on the waste management hierarchy that gives precedence to waste } \\
\text { reduction, standard treatment and proper disposal }\end{array}$ \\
\hline
\end{tabular}

\section{Research Methodology}

This section describes the methodology adopted throughout the research project. Research methodology is a guide to achieve the aim and objectives of the research. Qualitative research has been adopted in this paper. The methodology divided into three phase which are literature review from the previous research, data collection by using qualitative method and data analysis by content analysis. Qualitative approach is an approach for examining respondent perceptions based on their work experiences [27]. For this paper, challenges of illegal dumping activity have been explored by way of previous research. Then semi-structured interview has been prepared to identify the current practices of construction waste management and challenges of illegal dumping activities. Interview protocol has been prepared to ensure the reliability and validity of qualitative data. Samples selected based on related and expert in Malaysia construction waste management. Selection of respondents has been made based on the preliminary beforehand expectation.

\section{Result And Discussion}

This part discuss on result and discussion from data collection. The data collection has been involved with expert in construction waste management sector. Semi-structured interview has been used as a tool for data collection process and it has been take for average 30 minutes for the interviews duration. The interview questions are related to the challenges of current construction waste management and challenges on reducing illegal dumping activities in Malaysia construction industry. Next sub section will discuss on respondents background, findings and discussions. 


\subsection{Respondents Background}

Twenty respondents have been interviewed in this research. Working experience of respondents is at least 5 years and more. Table 2 show details of respondents that have been involved are highly experienced in construction waste management industry. Table 2 describes details of each respondent in terms of their profession and experience durations. In fact, all the respondents and organisations involved in waste management solve existing problems in construction waste differently. The respondents involved in this research work for different departments and company. However, all the respondents involved play important roles in their scope of work i.e. managing solid waste in the construction sector in Malaysia.

Table 2 - Details of respondents

\begin{tabular}{|c|c|c|c|}
\hline No & $\begin{array}{l}\text { Respondents } \\
\qquad(\mathrm{n}=\mathbf{2 0})\end{array}$ & Position & $\begin{array}{c}\text { Experience } \\
\text { (Years) }\end{array}$ \\
\hline 1 & R1 & Head of Department & 23 \\
\hline 2 & $\mathrm{R} 2$ & Head of Department & 7 \\
\hline 3 & R3 & Engineer & 6 \\
\hline 4 & $\mathrm{R} 4$ & Engineer & 8 \\
\hline 5 & R5 & Engineer & 5 \\
\hline 6 & R6 & Engineer & 4 \\
\hline 7 & R7 & Engineer & 6 \\
\hline 8 & $\mathrm{R} 8$ & Engineer & 8 \\
\hline 9 & R9 & Engineer & 5 \\
\hline 10 & R10 & Director & 18 \\
\hline 11 & R11 & Head of Department & 6 \\
\hline 12 & $\mathrm{R} 12$ & Head of Department & 5 \\
\hline 13 & R13 & Engineer & 16 \\
\hline 14 & R14 & Engineer & 5 \\
\hline 15 & R15 & Engineer & 12 \\
\hline 16 & R16 & Technical Assistant & 12 \\
\hline 17 & R17 & Technical Assistant & 14 \\
\hline 18 & R18 & $\begin{array}{l}\text { Technical Operations and } \\
\text { Management }\end{array}$ & 4 \\
\hline 19 & R19 & Technical Assistant & 3 \\
\hline 20 & $\mathrm{R} 20$ & $\begin{array}{l}\text { Technical } \\
\text { Assistant }\end{array}$ & 17 \\
\hline
\end{tabular}




\subsection{Challenges Reducing Illegal Dumping Activities}

Table 3 shows the findings data collection from the respondents. Table 3 shows the findings data from the interviews. As shown in table, there are involved with 20 respondents and most of them response the similar information. The high number of responses is awareness which 20 number respondent mentioned in the interview data. This findings shows that all respondents mentioned the lack of awareness among all the stakeholders and any parties are involved in managing construction waste towards the proper of construction waste management. Then 20 of respondents also mentioned facilities are the most challenging in managing construction waste management in Malaysia construction industry. The facilities are related to the type of landfill, number of landfill and equipment for managing construction waste. In addition, most of the responses from the respondents stated that cost, enforcement, guidelines, monitoring, implementation and cooperation. However, the data presented in Table 3 explain the conclusions of the information obtained through the interviews conducted. Details discussion will be discussed in next section.

Table 3 - Findings from interview

\begin{tabular}{|c|c|}
\hline Respondents & Findings \\
\hline R1 & $\begin{array}{ll}\text { - } & \text { Enforcement } \\
\text { - Guidelines } \\
\text { - Cooperation } \\
\text { - Implementation } \\
\text { - Awareness } \\
\text { - Facilities } \\
\text { - Cost }\end{array}$ \\
\hline $\mathbf{R} 2$ & $\begin{array}{ll}\text { - } & \text { Enforcement } \\
\text { - } & \text { Guidelines } \\
\text { - } & \text { Impoperation } \\
\text { - } & \text { Awarenentation } \\
\text { - Facilities } \\
\text { - Cost }\end{array}$ \\
\hline $\mathbf{R 3}$ & $\begin{array}{ll}\text { - } & \text { Enforcement } \\
\text { - } & \text { Guidelines } \\
\text { - } & \text { Cooperation } \\
\text { - Implementation } \\
\text { - Awareness } \\
\text { - Facilities } \\
\text { - } \text { Cost }\end{array}$ \\
\hline R4 & $\begin{array}{l}\text { - Enforcement } \\
\text { - Guidelines } \\
\text { - } \text { Cooperation } \\
\text { - Implementation } \\
\text { - Awareness } \\
\text { - Facilities } \\
\text { - } \text { Cost }\end{array}$ \\
\hline R5 & $\begin{array}{l}\text { - Enforcement } \\
\text { - Guidelines } \\
\text { - Cooperation } \\
\text { - Implementation } \\
\text { - Awareness } \\
\text { - Facilities } \\
\text { - } \text { Cost }\end{array}$ \\
\hline R6 & $\begin{array}{l}\text { - Enforcement } \\
\text { - Guidelines } \\
\text { - } \text { Cooperation } \\
\text { - Implementation } \\
\text { - Awareness } \\
\text { - Facilities } \\
\text { - Cost }\end{array}$ \\
\hline $\mathbf{R 7}$ & $\begin{array}{ll}\text { - } & \text { Enforcement } \\
\text { - } & \text { Guidelines } \\
\text { - } & \text { Cooperation }\end{array}$ \\
\hline
\end{tabular}




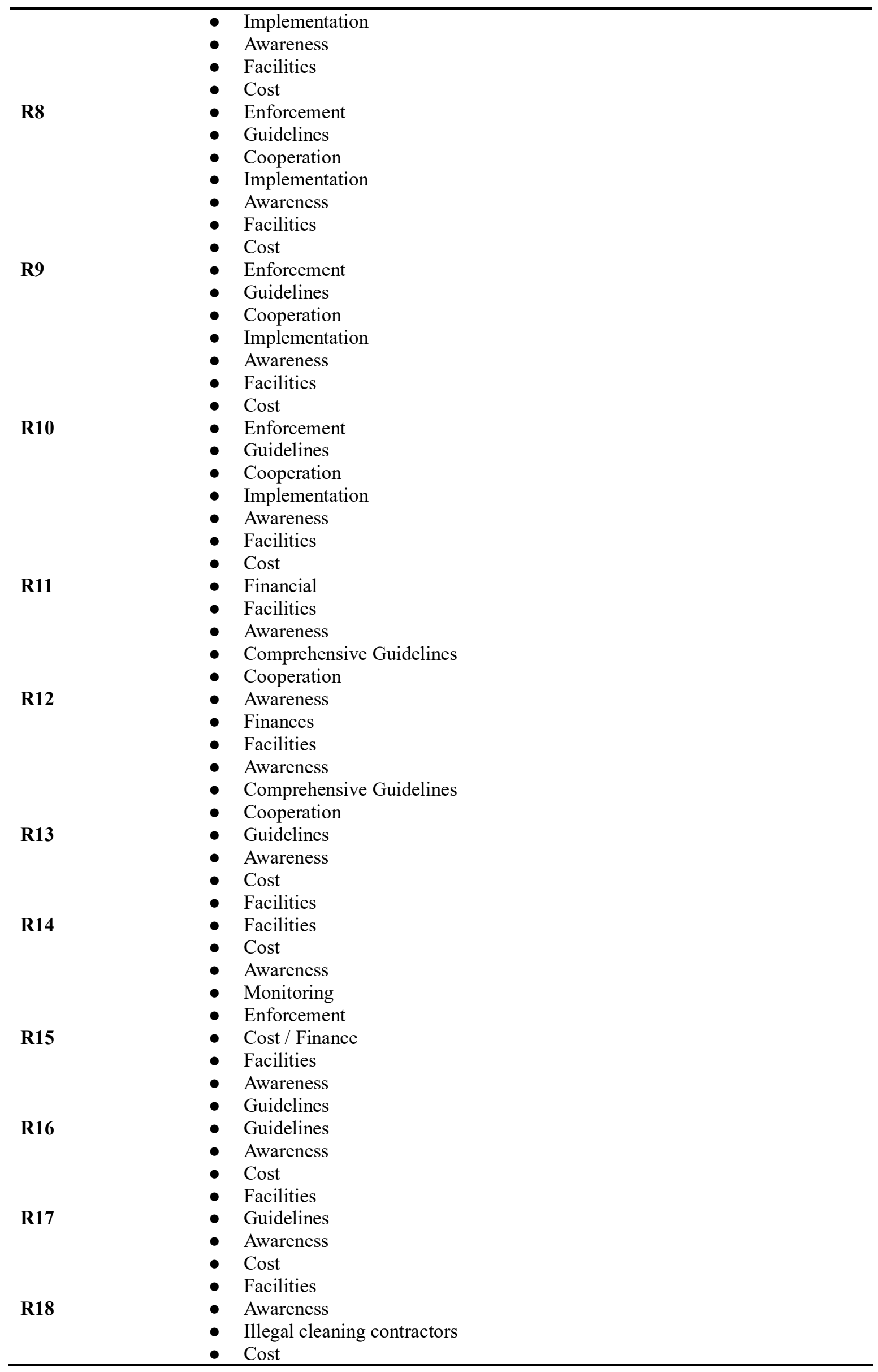




\begin{tabular}{ll}
\hline $\mathbf{R 1 9}$ & $\bullet$ Facilities \\
& - Access road to landfills \\
& $\bullet$ Awareness \\
& $\bullet$ Cost \\
& - Awareness \\
& $\bullet$ Facilities \\
& $\bullet$ Illegal cleaning contractors \\
& $\bullet$ Enforcement \\
\hline
\end{tabular}

\subsection{Significant Findings and Discussion}

In this section, significant findings has been discuss in details. Significant findings has been determine from the respondent's responses. There are the challenges from responses which cost, awareness, facilities, illegal cleaning contractors, enforcement, and access road to landfills, guidelines, cooperation, finance, and implementation. However only 3 most significant findings shows the high frequency from respondent's responses. Furthermore, Table 4 shows the most significant data of challenges from respondents.

Table 4 - Significant findings from interview

\begin{tabular}{|c|c|c|c|c|}
\hline Elements & No & Significant findings & $\mathbf{N}$ & Respondents \\
\hline \multirow{3}{*}{ Challenges } & $\mathrm{i}$ & Technology & 19 & $\begin{array}{l}\text { R1, R2, R3, R4, R5, R6, R7, R8, R9, } \\
\text { R10, R11, R12, R13, R14, R15, } \\
\text { R16, R17, R19, R20 }\end{array}$ \\
\hline & ii & Lack of Awareness & 20 & $\begin{array}{l}\text { R1, R2, R3, R4, R5, R6, R7, R8, R9, } \\
\text { R10, R11, R12, R13, R14, R15, } \\
\text { R16, R17, R18, R19, R20 }\end{array}$ \\
\hline & iii & Facilities & 20 & $\begin{array}{l}\text { R1, R2, R3, R4, R5, R6, R7, R8, R9, } \\
\text { R10, R11, R12, R13, R14, R15, } \\
\text { R16, R17, R18, R19, R20 }\end{array}$ \\
\hline
\end{tabular}

Findings showed that the significant elements with the highest frequencies are awareness, facilities and technology. All of the respondents agreed that lack of awareness is the biggest challenge in waste management based on the following statements:

'... Basically, we are facing big issues on handling human. Human errors are is a complicated matter by ensuring that they are in line with what has been set by the government...' (R2)

'... From my experience I has been faced with the people are not giving cooperation while they failed to fulfil our SOP by handling construction waste. These lacks of awareness are the big problems what we have been faced...' (R8)

'... Yes awareness among all participants are giving big problems to us. I try to find why is actually there are not giving cooperation for handling construction waste because they need to pay amount and hired the special contractor for handling this. It will increase their cost...' (R16)

'... To have good cooperation from construction parties are so difficult. They said that there will give high cooperation but at the end of the day, increasing number of illegal dumping are still found...' (R19).

It is difficult to increase awareness among construction players. This is because previous studies have proven that awareness is the highest barrier in the implementation of new methods or the improvement of environmental issues. Additionally, respondents believe that the lack of cooperation among construction parties has contributed to the increase in illegal dumping activities. Hence, more procedures are needed to implement good construction waste management (Faniran \& Caban, 2007). Similarly, all the respondents agreed that increasing the awareness of construction players can help reduce illegal dumping issues. This view was shared by the respondents in the following excerpts:

'... I believe that with this increasing awareness it is certain that all parties will have a high awareness in preserving the environment and managing the construction waste well...' (R1)

'...Based on my experience, when we in Japan, their government are not worried about the maintaining of waste, because the awareness among all people about the cleanliness is high. Additionally let's have a look in Singapore, their 
government has been implemented the legal for those people are throw rubbish at the public. This is definitely will help to increase the awareness among all peoples ...' (R3)

This statement shows that there are no problems with the awareness on waste issues in developed countries. Furthermore, the findings indicated that awareness among all construction parties on the management of construction waste is at a low level. As hinted by R11, most of the construction players are more concerned about the costs required to manage construction waste according to the SOP. This could lead to the disposal of construction waste at public areas.

Good facilities are important to ease the process of waste disposal. This coincides with the results from previous studies where it was found that there were inadequate facilities for the disposal of construction waste [12]. Supporting this notion, respondents R3, R5 and R12 mentioned that:

'... In Malaysia, the poor of facilities especially number of landfill are the constraints faced by Malaysia. These constraints have been taken by some parties to remove waste in public areas because they provide limited facilities provided by the government...' (R2)

'... Normally contractor complaint about the facilities provided by the government. They said they have to rent the RORO tank then they have to send waste at the located landfill which is far from construction site...' (R5)

'...If we have a good and enough facilities definitely there are no issues of illegal dumping activities. But the realities of constraint facilities have become a major challenge in the management of waste management in Malaysia. This is not unfortunate that the government releases hands in the provision of infrastructure but location constraints, financially in managing well are some of the reasons why these facilities are limited...' (R12)

The excerpts above demonstrate that challenges in terms of facilities are faced by all parties such as contractors, the government and so on. Additionally [28] stated that advanced facilities at landfills will help reduce illegal dumping activities. The lack of facilities may lead to the increase in illegal dumping activities. This happens when legal dumpsites are not properly manned or when there are no proper segregation of construction waste for recycling purposes. These wastes are regularly disposed of at the same disposal site as other types of solid waste resulting in a mixture of inert and organic materials at the landfill. Landfilling of construction waste is unsound and impractical, both economically and environmentally, because some of these wastes are recyclable and reusable [12]. Therefore, the introduction and promotion of recycling facilities and buy-back centers for construction waste can help reduce the quantity of construction waste disposed at dumpsites. Construction companies should be obliged to record and report the quantity of waste they generate.

Finally, 19 respondents agreed that technology is one of the challenges faced in construction waste management. Previous research studies identified that the success of construction waste management in countries such as China, the United Kingdom, Japan, Korea, and Singapore is due to the implementation of technology [29]. Additionally, Hong Kong applied low waste technology in the initial design stage and effectively reduced the generation of construction waste. In order to ascertain the challenges likely to lead to illegal dumping activities in Malaysia, the respondents were asked to give their opinions on the challenges faced in construction waste management. Their opinions include:

'... Based on my experience from develop country such as previously we have been in Japan and what we learnt is the technology implemented for construction waste management help to reduce the issues on illegal dumping activities. That is Malaysia lack on that...' R15

'... Yes Malaysia need to implement the technology to ensure that all parties especially construction players are recycling and follow as government suggested. The technology can be such as recycling machine, sorting machine, crusher machine and others new technology. For sure it will help to reduce the illegal dumping activities and generation of construction waste...' (R20)

In addition, the analysis indicated that issues related to illegal dumping activities in construction waste management require further research. This supports the literature review where stakeholders recommended extensive research on the improvement of construction waste management to reduce illegal dumping activities. Another institutionally related factor that emerged from the data analysis is the fact that the waste management system in Malaysia has not been fully implemented. Most of the respondents hinted that all parties are not too concerned with issues related to construction waste. Findings from previous research indicated that the illegal dumping of construction waste is on the rise.

Finally, the interview findings highlighted the current practices of construction waste management in the Malaysia construction industry need to be improved in order to reduce illegal dumping activities. Last but not least, it can be concluded that the scenario of construction waste management in Malaysia requires serious attention. The next section discusses the main factors of illegal dumping activities in the Malaysian construction industry.

\subsection{Summary Findings}

Illegal dumping activities generated throughout the construction waste from construction site to landfill. Illegal dumping is the greatest challenge in construction waste management at construction level. Among the issues that have been identified are insufficiently stringent legislations, lack of enforcement, inadequate facilities, lack of a collection 
network, low levels of awareness and the negative attitudes of the construction players. Potential ways to improve construction waste management have been identified for construction waste disposal at construction level [30]. Nevertheless, there are challenges faced by waste management practitioners in managing construction waste. Figure 1 shows the most significant challenges in current practices which have to focus in order to reduce the illegal dumping activities.

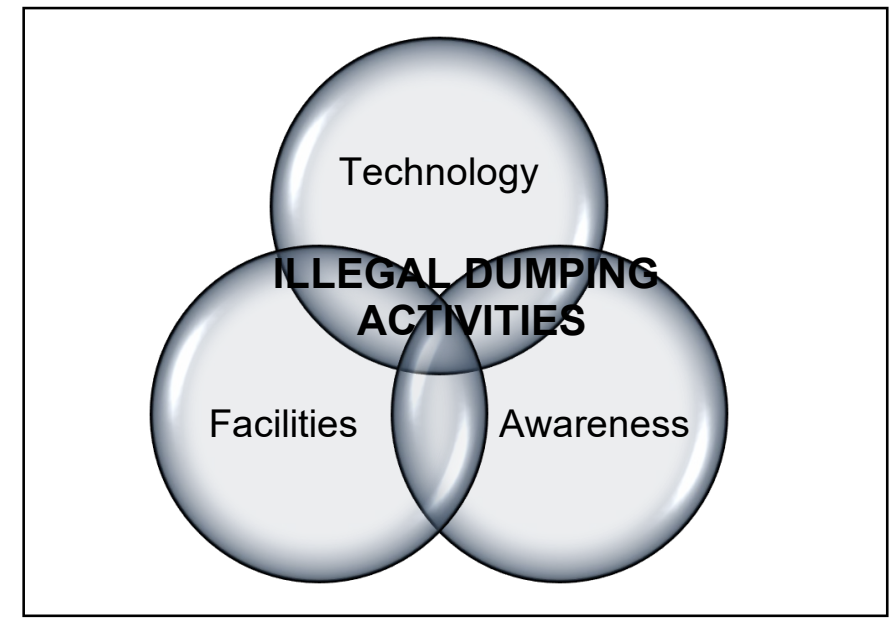

Fig. 1 - Current challenges for reducing illegal dumping activities

\section{Conclusion}

To achieve objective of this paper, the challenges on construction waste management in the Malaysian construction industry, problems related to illegal dumping activities, in construction waste management and the respondents' experience in construction waste management in Malaysia were reviewed.

\section{Acknowledgements}

The author would like to thank, Department of Construction Management, Faculty of Technology Management and Business Universiti Tun Hussein Onn Malaysia. The author also likes to thank Research Grant Q021, Sustainability of Bumiputera Entrepreneur in Construction Industry for supporting this research.

\section{References}

[1] Nagapan, S., Rahman, I. A., Asmi, A., Memon A. H., \& Latif, I. (2012). Issues on construction waste: The need for sustainable waste management, IEEE Colloquium Humanities Science Engineering, 325-330.

[2] Eusuf, M. A., Ibrahim, M. \& Islam, R., (2012). The construction and demolition waste in Klang Valley, Malaysia. Journal of the Malaysian Institute of Planners, 99-124.

[3] Yahaya, I., \& Zainal Abidin N. (2013). Commitment of Malaysian Contractors for Environmental Management Practices at Construction Site. International Journal of Sustainable Human Development. United Kingdom. Eduserv Group Publishing Division. 1(3), 119-127.

[4] Ismam, J. N., \& Ismail, Z. (2014). Sustainable Construction Waste Strategic Implementation Model. WSEAS Transactions on Environment and Development. ISSN:2224-3496.

[5] Abanda, H., Tah, J. H. M., Cheung, F. and Zhou, W. (2010). Measuring the embodied energy, waste, CO2 emissions, time and cost for building design and construction. In Computing in Civil and Building Engineering, Proceedings of the International Conference, Nottingham University Press, Paper 181, ISBN 978-1-907284-60-1

[6[ Becker, J., Knackstedt, R., \& Pöppelbuß, D. W. I. J. (2009). Developing maturity models for IT management. Business \& Information Systems Engineering, 1(3), 213-222.

[7] Sulaiman, N., \& Baldry, D. (2011). Care Practice in Public Residential Care Homes for the Elderly (PbRCHfE): The Application of Visual Method Using Computer Aided Qualitative Data Analysis Software (CAQDAS): NVivo 9.0. The Built \& Human Environment Review, 4(1).

[8] SWCorp Malaysia, Perbadanan Pengurusan Sisa Pepejal Dan Pembersihan Awam.(2015). Progress Report 2015. SWCorp Malaysia

[9] SWCorp Malaysia, Perbadanan Pengurusan Sisa Pepejal Dan Pembersihan Awam. (2016). Pengurusan Sisa Pepejal Bagi Projek Pembinaan. SWCorp Malaysia.

[10] Manaf, L. A., Samah, M. A. A., \& Zukki, N. I. M. (2011). Municipal solid waste management in Malaysia: Practices and challenges. Waste Management, 29(11), 2902-2906. doi:10.1016/j.wasman.2008.07.015 
[11] Yuan, H. P., \& Shen, L.Y. (2011). Trend of the research on construction and demolition waste management. Waste manage, 31, 670-679.

[12] Rahim, M. H. I. A.; Kasim, N.; Mohamed, I.; Zainal, R.; Sarpin, N.; Saikah, M. (2017). Construction Waste Generation in Malaysia Construction Industry: Illegal Dumping Activities. IOP Conference Series: Materials Science and Engineering, Volume 271, Issue 1, pp. 012040. DOI

[13] Pheng, L. S., \& Tan, S. K. L. (1998). How 'just-in-time' wastages can be qualified: case study of a private condominium project, Construction Management and Economics, 6(6), 621-635.

[14[ Stenis, J. (2004). Construction Waste Management Based on Industrial Management Models: A Swedish Case Study. doi: 10.1177/0734242X05050184.

[15] Wee, S. T. (2016). Senario Pengurusan Sisa Pepejal di Malaysia. Malaysia. Penerbit Universiti Tun Hussein Onn Malaysia.

[16] WRAP, Waste and Resources Action Programme., (2010). Welsh Assembly Government: Interim Statement on Policy for Construction and Demolition Waste., http://www.wrap.org.uk/construction/.

[17] Boussabaine, A. H. \& Yahya, K. (2006), Eco-costing of construction waste, Management of Environmental Quality, 17(1), 6-19.

[18] Alarcon, L. F. (1994), Tools for the identification and reduction of waste in construction projects,in Alarcon, L.F. (Ed.),

[19] Alsehaimi, A., Koskela, L. and Tzortzopoulos, P. (2013), Need for alternative research approaches in construction management: case of delay studies, Journal of Management in Engineering, 29(4), 407-413.

[20] Yates, J. K. (2013). Sustainable method for waste minimisation in construction. Construction Innovation Vol. 13 No 3. Emerald Group Publishing Limited 1471-175 DOI 10.1108/CI-Nov 2011-0054

[21]Kartam, N., Al-Mutair, N. A., \& Al-Humoud, J. (2004). Environment Management of Construction and Demolition waste in Kuwait. Waste manage, 24(10), 1049-1059.

[22] Ikau, R., Joseph, C., \& Tawie, R. (2016). Factor influencing waste generation in the construtcion industry in Malaysia. Procedia-social and behavioral sciences, 234, 11-18.

[23] Construction Industry Board Development. (2005). LESTARI 2005 Article. Construction Industry Board Development (CIDB).

[24] Agamuthu, P., Fauziah, S. H. and Khidzir, K. (2009). Evolution of solid waste management in Malaysia: impacts and implications of the solid waste bill, 2007. Material Cycles and Waste Management, 11(2), 96-103.

[25] Akadiri, P. O., and Fadiya, O. O. (2013). Empirical analysis of the determinants of environmentally sustainable practices in th e UK construction industry. Construction Innovation: Information, Process, Management, 13(2008). 352-373. doi:10.1108/CI-05-2012-0025

[26] Saeed, M.O., Hassan M. N., \& Mujeebu, M. A. (2009). Assessment of municipal solid waste generation and recyclable materials potential in Kuala Lumpur, Malaysia. Waste Management, 29(7), $2209-2213$. http://dx.doi.org/10.1016/j.wasman.2009.02.017

[27] Fellows, R. F., \& Lui, A. M. M. (2008). Research Methods for Construction. United States of America: Blackwell Publishing Ltd.

[28] Woon, K. S., \& Lo, I. M. C. (2013). Greenhouse gas accounting of the proposed landfill extension and advanced incineration facility for municipal solid waste management in Hong Kong. Science of the Total Environment, 458460, 499-507. doi:10.1016/j.scitotenv.2013.04.061

[29] Begum, R. A., Satari, S. K. \& Pereira, J. J., (2011). Waste Generation and Recycling: Comparison of Conventional and Industrialized Building Systems. American Journal of Environmental Sciences, 6(4), 383-388.

[30] Faniran, O. O., \& Caban, G., (2007). Minimizing waste on construction project sites. Eng. Constr. Archit. Manage, $5(2), 182-188$. 